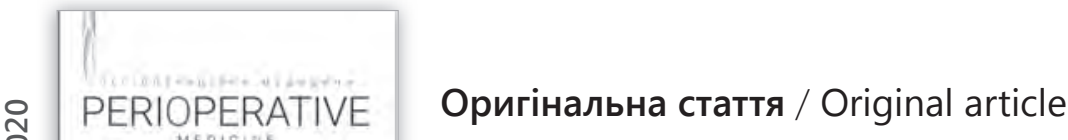 \\ Journal of PERIOPERATIVE MEDICINE \\ Медицина Періопераційна • Периоперационная Медицина \\ DOI: 10.31636/prmd.v3i2.4 \\ Сравнительная характеристика эффективности антисептических препаратов Декасан (DECASAN) Юрия- Фарм и Кутасепт Г (CUTASEPT G) при лечении гнойно- воспалительных заболеваний различной локализации
}

\author{
Лыхман В. Н., Ткач С. В. \\ ГУ “Институт общей и неотложной хирургии им. В.Т. Зайцева НАМН Украины”, Харьков
}

Резюме. Актуализациия: Высокая летальность как следствие различных инфекцционных осложнений (в 42,5\% случаев они являются непосредственной причиной), постоянно увеличивающаяся частота гнойновоспалительных заболеваний, а также рост микробной устойчивости к антибактериальным препаратам вынуждают искать решение проблемы среди местных антисептиков.

Цель исследования. Сравнить эффективность антисептиков - Декасан (DECASAN) Юрия-Фарм и Кутаcenт Г (CUTASEPT G) при лечении гнойно-воспалительных заболеваний различной локализациии.

Материалы и методы. В исследовании приняли участие 30 пациентов с гнойно-воспалительными заболеваниями различной локализации. В соответствии с выбранной тактикой местной антисептической терапии больные были разделены на две группы. У больных первой исследуемой группы ( $n=15$; средний возраст - 49,73 \pm 6,35 года) антисептическая обработка проводилась лекарственным средством на основе 0,02 \% декаметоксина (Декасан). Во второй группе ( $n=15$; средний возраст - 51,4 \pm 5,14 года) обработка проводилась дезинфицирующим средством (кожным антисептиком) “Кутасепт Г”. Забор материала для микробиологического исследования (бактериологический посев) проводили до начала лечения, на 3 и 5 сутки после начала лечения. Анализ вероятности проводился по t-критерию Стьюдента. Статистически значимой разнииу между показателями считали при вероятности справедливости нулевой гипотезы менее $5 \%$ $(p<0,05)$.

Результаты. Анализируя полученные результаты бактериологического исследования обоих групп, в первой, когда применялся Декасан, и во второй, после применения Кутасепта Г, установили, что в начале лечения имела место выраженная микробная колонизация ран, достоверно не отличавшаяся от таковой y пациентов обеих групп наблюдения $(p<0,05)$. Микробиологическое наблюдение за течением гнойновоспалительного процесса в динамике свидетельствовало о значительно замедленном процессе микробного очищения во второй группе (Кутасепт Г), состояние на 5 сутки было $\lg (8,8 \pm 0,4) \mathrm{KOE} /$ мл, в то время когда у пацииентов первой группы сравнения - количество микроорганизмов в 1 мл раневого содержимого, выраженное в $\mathrm{lg}$, составило $(4,8 \pm 0,4) \mathrm{KOE} /$ мл, что не превышало критически допустимый уровень. 
Полученные показатели были достоверно выше, нежели при применении Кутасепта Г ( $p<0,05)$, которые в два раза превышали уровень микробной колонизации по сравнению с обработкой ран 0,02 \% раствором декаметоксина $(p<0,001)$.

Заключение. Применение антисептика 0,02 \% декаметоксина на 5 сутки обеспечивает уменьшение количества условно-патогенных микроорганизмов $\lg (4,8 \pm 0,4) \mathrm{KOE} /$ мл, что в 1,9 раза ниже $(p<0,05)$ по сравнению с применением Кутасепта Г, создавая условия для заселения нормальной микробиотой кожи (Corynebacterium spp., S. epidermidis).

Антисептический препарат Декасан характеризуется хорошей лечебной способностью благодаря высокой противомикробной активности, изотоничности, что дает возможность успешно применять его у больных с гнойно-воспалительными заболеваниями различной локализации. Помимо этого, применение Декасана способствует быстрому очищению ран от гнойно-некротического содержимого и образованию в них грануляциионной ткани.

Ключевые слова: Декаметоксин, гнойно-воспалительные заболевания, S. aureus, Ps. aeruginosa, антибиотикорезистентность

\section{Актуализация}

В настоящее время инфекцию определяют как процесс внедрения и развития микробов в ткани организма с последующим взаимодействием между макро- и микроорганизмами.

Хирургические заболевания, в основе которых лежит инфекционный процесс, составляют до $1 / 3$ всех хирургических болезней. Различные инфекционные осложнения в 42,5 \% случаев являются непосредственной причиной летальных исходов. Во всех странах мира отмечается увеличение частоты гнойно-воспалительных заболеваний. Это обусловлено увеличением числа штаммов микроорганизмов, устойчивых к действию антибактериальных препаратов, а также изменениями иммунологической резистентности населения под воздействием окружающей среды. Ежегодно в лечебных учреждениях лечатся миллионы больных с гнойно-воспалительными заболеваниями, что требует значительных финансовых затрат [1, 2].

Согласно данным отечественной и зарубежной литературы, наиболее часто в настоящее время встречаются: Staphilococcus aureus, Pseudomonas aeruginosa, Escherichia coli, Enterococcus, Enterobacter, Streptococcus, Proteus vulgaris, Pneumococcus [2].

Вследствие широкого применения антибиотиков и их мутагенного действия на микроорганизмы последние, как правило, приобретают устойчивость к большинству антибактериальных средств. Лекарственная устойчивость стафилококков, выделенных у больных с гнойной инфекцией, превышает $70 \%$. Такую же устойчивость выявляют у палочки синезелёного гноя (Pseudomonas aeruginosa), чем можно объяснить её возрастающую роль при ослож- нении ожогов и ран. Большое значение в развитии гнойной хирургической инфекции в связи с распространённостью, стойкостью и возможностью роста в анаэробных и аэробных условиях имеет кишечная палочка (Escherichia coli) [2, 6, 9].

Таким образом, наиболее частые возбудители инфекции характеризуются устойчивостью к традиционным антибактериальным средствам, что определяет сложность лечения гнойных заболеваний.

Известными средствами для местного лечения гнойно-воспалительных ран являются антисептики. Сейчас в практике используются такие антисептики, как фурацилин, хлоргексидина биглюконат, перекись водорода, калия перманганат, производные йода, декаметоксин и др. Основным обоснованием использования антисептиков при гнойно-воспалительных заболеваниях является борьба с инфекционными осложнениями для улучшения условий ранозаживления. Вместе с тем антисептики считаются альтернативой широкому использованию антибиотиков при лечении больных с ранами [1,2-7].

\section{Цель исследования}

Изучить и провести сравнительную характеристику эффективности применения антисептических препаратов - Декасан (DECASAN) Юрия-Фарм и Кутасепт Г (CUTASEPT G) при лечении гнойно-воспалительных заболеваниях различной локализации.

\section{Материалы и методы}

В исследовании приняли участие 30 пациентов

с гнойно-воспалительными заболеваниями раз- 
личной локализации; это, в частности, фурункулы, абсцессы, трофические язвы, парапроктиты, медиастиниты. Все пациенты лечились в отделении хирургических инфекций ГУ “Института общей и неотложной хирургии им. В. Т. Зайцева НАМН Украины” (2020 г.). Больным проводилось комплексное обследование и подобрано индивидуальное лечение в соответствии с патологией.

Поскольку антисептики являются неотъемлемой частью комплексной терапии при гнойно-воспалительных заболеваниях и в настоящие время признаются некой альтернативой антибиотикотерапии, стал вопрос об эффективности применения самых распространенных из них. С целью сравнительной оценки использовали одни из наиболее часто используемых антисептических средств - Декасан (DECASAN) Юрия-Фарм и Кутасепт Г (CUTASEPT G).

Декасан (производство “Юрия-Фарм”, 0,02\% изотонированый хлоридом натрия раствор декаметоксина) - антисептик, раствор декаметоксина для наружного и внутриполостного (брюшная и плевральная полости) применения. Обладает широким спектром антимикробного действия, применяется для орошения слизистых оболочек, раневой поверхности, ингаляций при лечении инфекционновоспалительных процессов различной этиологии [сайт]. Декаметоксин представляет собой белый мелкокристаллический порошок с едва заметным характерным запахом, легко растворяется в воде, $95 \%$ спирте и практически не растворяется в эфире. Препарат декаметоксин соответствует АНД (Регистрационное удостоверение от 09.10.2002 № П.10.02/05401). Антимикробный спектр декаметоксина изучен на 350 штаммах микроорганизмов (бактерии, вирусы, грибы) [3, 4, 8].

Кутасепт $Г$ - антисептическое средство, избавляющее участок от микробной среды и одновременно обеспечивающее его обезжиривание. Раствор только для наружного применения, спиртовой, прозрачный, красно-коричневого цвета. Средство обладает пролонгированным бактерицидным, фунгицидным, туберкулоцидным действием. Спиртовая составляющая препарата одновременно с быстрым эффектом антимикробного действия обеспечивает обезжиривание и очистку кожи, а также проникновение бензалкония хлорида в глубокие слои кожи, за счет чего обеспечивается пролонгированное действие препарата. Кутасепт Г способствует эффективному прилипанию хирургической пленки после высыхания средства $[7,8]$.

В соответствии с выбранной тактикой местной антисептической терапии больные были разделены на две группы. У больных первой исследуемой груп- пы $(\mathrm{n}=15$; средний возраст $-49,73 \pm 6,35$ года $)$ антисептическая обработка проводилась лекарственным средством на основе $0,02 \%$ декаметоксина (Декасан). Во второй группе $(\mathrm{n}=15$; средний возраст - 51,4 \pm 5,14 года) обработка проводилась дезинфицирующим средством (кожным антисептиком) “Кутасепт Г”.

Забор материала для микробиологического исследования (бактериологический посев) проводили до начала лечения, на 3 и 5 сутки после начала лечения. Микробиологические исследования качественного и количественного состава микробиоты проводили в соответствии с общеизвестными методами исследования в условиях бактериологической лаборатории ГУ “Института общей и неотложной хирургии им. В. Т. Зайцева НАМН Украины”. А также дважды исследовали изменения клинического анализа крови до и после проводимого лечения.

Представленные в статье результаты обработаны статистически посредством использования программного обеспечения для обработки статистических данных Microsoft Excel 2016 и библиотеки matplotlib языка программирования Python. Анализ вероятности проводился по t-критерию Стьюдента. Статистически значимой разницу между показателями считали при вероятности справедливости нулевой гипотезы менее 5 \% $(\mathrm{p}<0,05)$.

\section{Результаты и обсуждение}

В первой исследуемой группе от пациентов ( $\mathrm{n}=$ 15), которым проводилась обработка антисептическим средством 0,02 \% декаметоксином, был сделан бактериологический посев до обработки, в котором обнаружены 28 штаммов микроорганизмов. Количественное содержание микроорганизмов в экссудате, выраженное в десятичных логарифмах, достигало $\lg (9,7 \pm 0,4) \mathrm{KOE} /$ мл. Наиболее распространенными изолятами условно-патогенных бактерий были S. aureus (35,5\%), E. coli $(30,2 \%)$ и $P$ s. aeruginosa $(17,1 \%)$.

На 3 -и сутки наблюдения от пациентов этой же группы наблюдения всего было выделено 16 микроорганизмов, среди них доминировали $S$. aureus $(30,5 \%)$, E. coli $(25,1 \%)$ и Ps. aerug. $(9,7 \%)$. Уровень микробной колонизации, выраженный в десятичных логарифмах, составил $\lg (9,1 \pm 0,3) \mathrm{KOE} /$ мл. На 5 -е сутки, несмотря на видовое разнообразие среди выделенных микроорганизмов (28 изолят), зарегистрировано существенное снижение (7 штаммов) микробной колонизации в динамике к количеству, составившему соответственно $\lg (4,8 \pm 0,4) \mathrm{KOE} / \mathrm{мл}$ и не превышавшему критически допустимый уро- 
Таблица 1. Результаты бактериологического исследования (количественная характеристика) по дням (группа № 1, Декасан)

\begin{tabular}{|c|c|c|c|}
\hline № ח & До обработки & 3 сутки & 5 сутки \\
\hline 1 & $5 \times 10^{8}$ & $3 \times 10^{5}$ & Не дали роста \\
\hline 2 & $6 \times 10^{7}$ & Не дали роста & Не дали роста \\
\hline 3 & $9 \times 10^{7}$ & $3 \times 10^{5}$ & $2 \times 10^{5}$ \\
\hline 4 & $9 \times 10^{8}$ & $5 \times 10^{8}$ & $3 \times 10^{6}$ \\
\hline 5 & $6 \times 10^{7}$ & $4 \times 10^{5}$ & $4 \times 10^{4}$ \\
\hline 6 & $10 \times 10^{6}$ & $4 \times 10^{4}$ & Не дали роста \\
\hline 7 & $8 \times 10^{8}$ & $3 \times 10^{6}$ & Не дали роста \\
\hline 8 & $7 \times 10^{8}$ & $5 \times 10^{5}$ & Не дали роста \\
\hline 9 & $5 \times 10^{8}$ & Не дали роста & Не дали роста \\
\hline 10 & $7 \times 10^{7}$ & $3 \times 10^{5}$ & $2 \times 10^{5}$ \\
\hline 11 & $9 \times 10^{8}$ & $9 \times 10^{8}$ & $3 \times 10^{6}$ \\
\hline 12 & $6 \times 10^{7}$ & $4 \times 10^{5}$ & $4 \times 10^{4}$ \\
\hline 13 & $10 \times 10^{6}$ & $4 \times 10^{4}$ & Не дали роста \\
\hline 14 & $5 \times 10^{8}$ & $3 \times 10^{6}$ & Не дали роста \\
\hline 15 & $10 \times 10^{6}$ & $6 \times 10^{5}$ & $4 \times 10^{4}$ \\
\hline
\end{tabular}
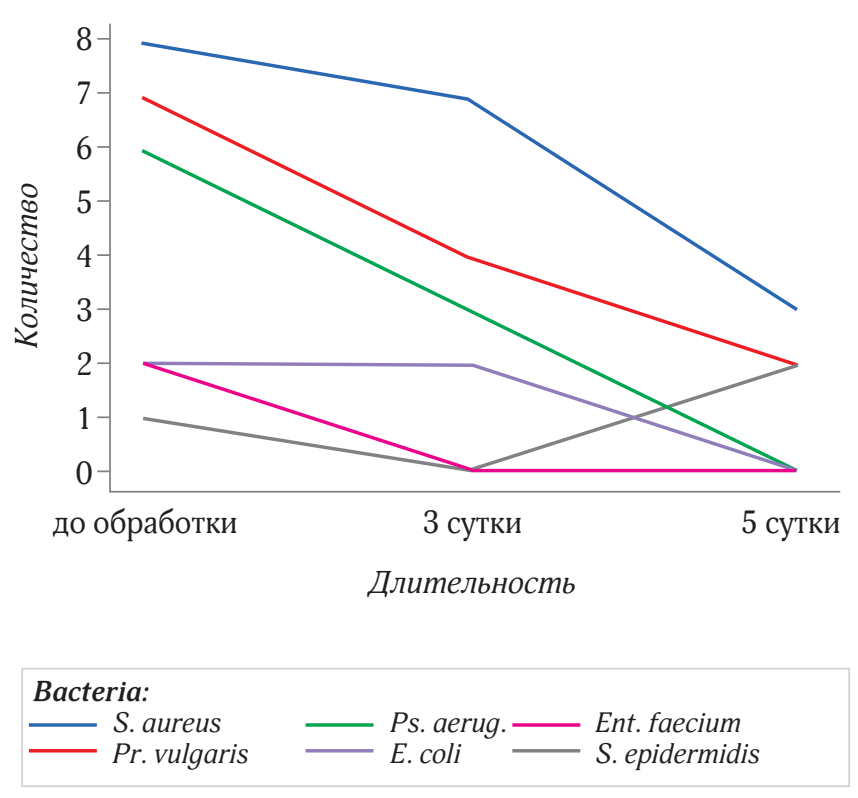

Рис. 1. Динамика снижения количества штаммов микроорганизмов по дням (группа № 1, Декасан) вень (lg 5 KOE/мл). Количество микроорганизмов, которые составляли значительный процент, существенно снизилось: S. aureus - 15,2 \%, E. coli - 9,6 \% (табл. 1).

При применении Декасана получена положительная динамика снижения штаммов и количества колоний микроорганизмов, что свидетельствует о высокой эффективности данного препарата (рис. 1). А также отмечается улучшение показателей клинического анализа крови от момента начала до конца терапии. В частности, нормализация лейкоцитарной формулы и снижение СОЭ.

Во второй группе наблюдения (n = 15) антисептическая обработка пациентам осуществлялась препаратом Кутасепт Г. Вначале был сделан бактериологический посев до обработки, в котором обнаружены 32 штамма микроорганизмов. Количественное содержание микроорганизмов в экссудате, выраженное в десятичных логарифмах, достигало $\lg (9,6 \pm 0,4) \mathrm{KOE} /$ мл. Наиболее распространенными изолятами условно-патогенных бактерий были S. aureus (45,3\%), Ps. aerug. $(37,3 \%)$ и Pr. vulgaris $(30,1 \%)$.

На 3 сутки наблюдения от пациентов этой же группы наблюдения всего было выделено 27 микроорганизмов, среди них доминировали $S$. aureus (35,2\%), Pr. vulgaris (25,3\%) и Ps. aerug. (30,7\%). Уровень микробной колонизации, выраженный в десятичных логарифмах, составил:

$$
\lg (9,1 \pm 0,3) \mathrm{KOЕ} / \text { мл. }
$$

На 5 сутки, несмотря на видовое разнообразие среди выделенных микроорганизмов (32 изолят), зарегистрировано снижение (18 штаммов) микробной колонизации в динамике к количеству, составившему соответственно $\lg (8,8 \pm 0,4) \mathrm{KOE} / \mathrm{Mл}$, которое превышает критически допустимый уровень (lg $5 \mathrm{KOE} /$ мл). Количество микроорганизмов, составлявших значительный процент, снизилось: S. aureus - 20,2 \%, Ps. aerug. - 9,6 \% (табл. 2). Динамика уменьшения количества микроорганизмов отображена графически (рис. 2).

Анализируя полученные результаты бактериологического исследования обеих групп, в первой, когда применялся Декасан, и во второй, после применения Кутасепта Г, было установлено, что в начале лечения имела место выраженная микробная колонизация ран, достоверно не отличавшаяся от таковой у пациентов обеих групп наблюдения ( $\mathrm{p}<0,05)$. Микробиологическое наблюдение за течением гнойно-воспалительного процесса в динамике свидетельствовало о значительно замедленном процессе микробного 
Таблица 2. Результаты бактериологического исследования (количественная характеристика) по дням (группа № 2, Кутасепт Г)

\begin{tabular}{|c|c|c|c|}
\hline № ח & До обработки & 3 сутки & 5 сутки \\
\hline 1 & $8 \times 10^{8}$ & $8 \times 10^{8}$ & $5 \times 10^{8}$ \\
\hline 2 & $7 \times 10^{7}$ & $7 \times 10^{6}$ & $4 \times 10^{5}$ \\
\hline 3 & $9 \times 10^{8}$ & $9 \times 10^{8}$ & $5 \times 10^{8}$ \\
\hline 4 & $9 \times 10^{7}$ & $9 \times 10^{7}$ & Не дали роста \\
\hline 5 & $6 \times 10^{7}$ & $4 \times 10^{7}$ & $4 \times 40^{7}$ \\
\hline 6 & $9 \times 10^{7}$ & $7 \times 10^{7}$ & $5 \times 10^{7}$ \\
\hline 7 & $5 \times 10^{7}$ & $5 \times 10^{7}$ & Не дали роста \\
\hline 8 & $8 \times 10^{7}$ & $5 \times 10^{7}$ & $5 \times 10^{7}$ \\
\hline 9 & $8 \times 10^{8}$ & $8 \times 10^{8}$ & $5 \times 10^{8}$ \\
\hline 10 & $6 \times 10^{7}$ & $6 \times 10^{7}$ & $4 \times 10^{5}$ \\
\hline 11 & $9 \times 10^{8}$ & $9 \times 10^{8}$ & $5 \times 10^{8}$ \\
\hline 12 & $9 \times 10^{7}$ & $9 \times 10^{7}$ & $7 \times 10^{7}$ \\
\hline 13 & $6 \times 10^{7}$ & $4 \times 10^{7}$ & $4 \times 10^{7}$ \\
\hline 14 & $5 \times 10^{7}$ & $4 \times 10^{7}$ & $4 \times 10^{7}$ \\
\hline 15 & $8 \times 10^{7}$ & $5 \times 10^{7}$ & Не дали роста \\
\hline
\end{tabular}

очищения во второй группе (Кутасепт Г); состояние на 5 сутки было $\lg (8,8 \pm 0,4) \mathrm{KOE} /$ мл, в то время когда у пациентов первой группы сравнения количество микроорганизмов в 1 мл раневого содержимого, выраженное в $\lg$, составило $(4,8 \pm 0,4) \mathrm{KOE} /$ мл, что не превышало критически допустимый уровень. Полученные показатели были достоверно выше, нежели при применении Кутасепта Г ( $<<0,05)$, что в два раза превышали уровень микробной колонизации по сравнению с обработкой ран 0,02 \% раствором декаметоксина $(\mathrm{p}<0,001)$.

\section{Заключение}

Применение антисептического средства 0,02\% декаметоксина в течение периода лечения пациентов с гнойно-воспалительными заболеваниями

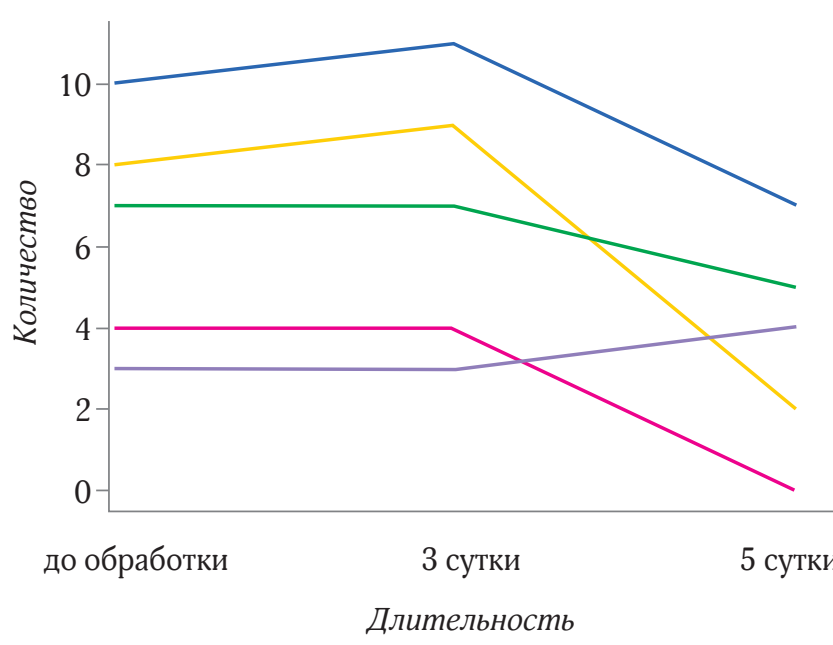

Bacteria:

$\begin{array}{ll}- \text { S. aureus } & \text { Ps. aerug. }- \text { Ent. faecium } \\ \text { Pr. vulgaris } & \text { E.coli }\end{array}$

Рис. 2. Динамика снижения количества штаммов микроорганизмов по дням (группа №2, Кутасепт Г)

на 5 сутки обеспечивает уменьшение количества условно-патогенных микроорганизмов $\lg (4,8 \pm 0,4)$ $\mathrm{KOE/мл,} \mathrm{что} \mathrm{в} 1,9$ раза ниже $(\mathrm{p}<0,05)$ по сравнению с применением Кутасепта Г, создавая условия для заселения нормальной микробиотой кожи (Corynebacterium spp., S. epidermidis).

Антисептический препарат Декасан характеризуется хорошей лечебной способностью благодаря высокой противомикробной активности, изотоничности, что дает возможность успешно применять его у больных с гнойно-воспалительными заболеваниями различной локализации. Помимо этого, применение Декасана способствует быстрому очищению ран от гнойно-некротического содержимого и образованию в них грануляционной ткани.

Опыт длительного применения Декасана показывает, что препарат хорошо переносят больные - без токсических воздействий на организм, без побочных явлений и аллергических проявлений. В дальнейшем целесообразно расширить исследования свойств данного препарата у больных с различной локализацией гнойно-воспалительных заболеваний. 


\title{
Efficacy comparative characteristics of antiseptic DECASAN Yuria-Pharm and CUTASEPT $G$ in the treatment of purulent inflammatory diseases of various localization
}

\author{
Lykhman V. N., Tkach S. V. \\ SI "V. T. Zaitsev Institute of General and Emergency Surgery of the National Academy of Medicine of Ukraine", Kharkiv
}

\begin{abstract}
Background: High mortality because of various infectious complications (immediate cause in $42.5 \%$ of cases), the ever-increasing frequency of purulent inflammatory diseases, as well as the growth of microbial resistance to antibacterial drugs, force to seek a solution to the problem among local antiseptics.
\end{abstract}

Aim: to compare the effectiveness of antiseptics DECASAN Yuria-Pharm and CUTASEPT G in the treatment of purulent inflammatory diseases of different localization.

\begin{abstract}
Materials and methods: The study involved 30 patients with purulent inflammatory diseases of various localizations. Patients were divided into two groups, according to the chosen tactics of local antiseptic therapy, in patients of the first study group ( $n=15$; mean age $-49.73 \pm 6.35$ years) antiseptic treatment was performed with a drug based on $0.02 \%$ decamethoxine (Decasan). In the second group ( $n=15$; mean age - $51.4 \pm 5.14$ years) treatment was performed with a disinfectant (skin antiseptic) "Cutasept $G$ ". Collection of material for microbiological examination (bacteriological culture) was performed before treatment, 3 and 5 days after treatment. Probability analysis was performed according to Student's t-test. A statistically significant difference between the indicators was considered when the probability of validity of the null hypothesis was less than $5 \%(p<0.05)$.
\end{abstract}

Results: Analyzing the results of bacteriological examination of both groups, in the first, where Decasan was used and in the second, with the use of Cutasept $G$, it was found that at the beginning of treatment there was a pronounced microbial colonization of wounds, not significantly different among patients in both groups $(p<0.05)$. Microbiological observation of the course of purulent-inflammatory process in the dynamics showed a significantly slowed down process of microbial purification in the second group (Cutasept $G$ ), the condition for 5 days was $\lg$ ( $8.8 \pm$ $0.4) \mathrm{CFU} / \mathrm{ml}$. At that time for patients of the first comparison group the number of microorganisms in $1 \mathrm{ml}$ of wound contents, expressed in Ig, was (4.8 \pm 0.4$) \mathrm{CFU} / \mathrm{ml}$, which does not exceed the critical level. The obtained values were significantly higher than with Cutasept $G(p<0.05)$, which was twice higher than the level of microbial colonization compared to the treatment of wounds with $0.02 \%$ decamethoxine solution $(p<0.001)$.

Conclusions: The use of antiseptic $0.02 \%$ decamethoxine for 5 days provides a reduction in the number of opportunistic pathogens $\lg (4.8 \pm 0.4) \mathrm{CFU} / \mathrm{ml}$, which is 1.9 times lower $(p<0.05)$ compared with the use of Cutasept $G$, creating conditions for the settlement of normal microbiotic skin (Corynebacterium spp., S. epidermidis). Antiseptic Dekasan is characterized by good healing properties due to its high antimicrobial activity, isotonicity, which makes it possible to use it successfully in patients with purulent inflammatory diseases of various localizations. In addition, the use of Dekasan promotes rapid cleansing of wounds from purulent-necrotic contents and formation of granulation tissue in them.

Key words: Decametoxine, purulent inflammatory diseases, S. aureus, Ps. aeruginosa, antibiotic resistance.

\section{Background}

The current infection can be defined as the process of the introduction and growth of microbes in the body tissue with a subsequent interaction between macro- and microorganisms.

In surgical disease, which have infectious process accounts up to one third of all the surgical diseases. In various infectious complications, $42.5 \%$ of the cases outcome as a direct cause of deaths. In all countries of the world, there is a notable increase in the frequency of purulent inflammatory diseases. This is due to an increase in strains of microorganisms resistant to antibacterial drugs, also the population under the influence of sur- 
rounding environment gets the changes in immunological resistance. Every year, millions of patients with purulent inflammatory diseases are treated in medical institutions, that requires significant financial expenses [1,2].

As per data of domestic and foreign literature, the most commonly encountered microorganisms are Staphilococcus aureus, Pseudomonas aeruginosa, Escherichia coli Enterococcus, Enterobacter, Streptococcus, Proteus vulgaris, Pneumococcus [2].

As a result of widespread use of antibiotics and their mutagenic effects on microorganisms, it's outcome can be characterized by sustainability to most antibacterial agents. Drug resistance to Staphilococcus in patient with purulent infection surpasses $70 \%$. The very sane resistance can be seen in rod shaped blue-green pus (Pseudomonas aeruginosa), which explains its increasing role in cases with complication of burns and wounds. Escherichia coli is of great importance in growth of purulent surgical infection due its prevalence, resistance and growth potential in anaerobic and aerobic conditions $[2,6,9]$.

In the same way the most common pathogens of infection can be characterized by resistance to the traditional antibacterial agents, which defines its complexities in treatment of purulent diseases.

The known agents for the local treatment of purulent-inflammatory wounds are antiseptics. Nowadays the antiseptics used in practice are furacilin, chlorhexidine bigluconate, hydrogen peroxide, potassium permanganate, povidone-iodine, decamethoxine and others. The main ground for the use of antiseptics in purulent inflammatory diseases is to fight against the infectious complications to improve wound healing conditions. It can be considered that antiseptic can be used alternatively than a widespread use of antibiotics in the treatment of patients with wounds $[1,2-7]$.

The aim is to study and conduct comparative characteristics of the effectiveness in use of antiseptic drugs Decasan Yuria-pharm and Cutasept $G$ in the treatment of purulent inflammatory diseases of different localization.

\section{Methods and materials}

The study involved 30 patients with purulent inflammatory diseases of various localization, in particular patients with: furuncle, abscesses, trophic ulcers, paraproctitis, mediastinitis. All patients were treated at the Department of Surgical Infections, SI "V. T. Zaitsev Institute of General and Emergency Surgery of the National Academy of Medicine of Ukraine. Patients underwent a comprehensive examination and selective individual treatment in accordance with the pathology. Since antiseptics are an integral part of complex thera- py for purulent inflammatory diseases and are currently recognized as a kind of alternative to antibiotic therapy, the question of the effectiveness of the most common ones has become a question. For the purpose of comparative evaluation, one of the most commonly used antiseptic agents was used - DECASAN Yuri-Pharm and Cutasept G.

Dekasan (manufactured by Yuria-Pharm, $0.02 \%$ saline solution of sodium chloride decamethoxine), is an antiseptic decamethoxine solution for external and internal body cavities (abdominal and pleural cavities). It has a wide spectrum of antimicrobial action, is used for irrigation of the mucous membranes, wounded surfaces, inhalations in the treatment of infectious and inflammatory processes of various etiologies [site]. Decamethoxine is fine crystalline powder characterized with a faint odor, easily soluble in water, $95 \%$ alcohol and practically insoluble in ether. The drug decamethoxine meets with the AND (Registration certificate from 10.10.2002 No.P.10.02/05401). The antimicrobial spectrum of decamethoxine was studied on 350 strains of microorganisms (bacteria, viruses, fungi) [3, 4, 8].

Cutasept $G$ - an antispetic agent, which eliminates the microbial activitiy and at the same time ensures that microbial activity is decreasing overall. This agent is only for external use, which is alcoholic transparent redbrown color.

The agent has a prolonged bactericidal, fungicidal, tuberculocidal effect. The alcohol component of the drug simultaneously with the rapid effect of antimicrobial action provides degreasing of skin cleansing, as well as penetration of Benzalkonium chloride into the deeper layers of the skin, which ensures a prolonged effect of the drug. Benzalkonium chloride contributes to the effective adhesion of the surgical film after agent is dry [7, 8].

In the chosen tactics of local antiseptic therapy, patients were divided into two groups. In patients of the first study group $(n=15$; average age $-49.73 \pm 6.35$ years), antiseptic treatment was carried out with a drug based on $0.02 \%$ decamethoxine (Dekasan). In the second study group $(\mathrm{n}=15$; average age $-51.4 \pm 5.14$ years $)$, the treatment was carried out with disinfectant (skin antiseptic). "Cutasept G"

The sampling of material for microbiological research (bacteriological culture) was carried out before treatment started, on the $3^{\text {rd }}$ and $5^{\text {th }}$ day after the start of treatment. Microbiological studies of the qualitative and quantitative composition of microbiota were carried out in accordance with well-known research methods in the bacteriological laboratory of DU "V. T. Zaitsev Institute of General and Emergency Surgery of the National Academy of Medicine of Ukraine, Department of Surgical Infections. The study was carried out twice to see the 
changes in the clinical analysis of blood before and after treatment.

The results presented in this article were processed statistically by using statistical processing software Microsoft Excel 2016 and the library matplotlib of Python programming language. The probability analysis was carried out according to the criteria of Student's t-test. The difference between the indicators was considered statistically significant where the probability of validity of the null hypothesis was less than $5 \%(p<0.05)$.

\section{Results and conclusions}

In the first study group from patients $(\mathrm{n}=15)$, who were treated with an antiseptic agent of $0.02 \%$ decamethoxine, bacteriological culture was done before treatment, in which 28 strains of microorganisms were found. The quantitative content of microorganisms in the exudate, expressed in decimal logarithms, reached lg $(9.7 \pm$ $0.4) \mathrm{CFU} / \mathrm{ml}$. The most common isolates found were of bacteria S. aureus (35.5\%), E. coli (30.2\%) and P. aeruginosa $(17.1 \%)$.

On the $3^{\text {rd }}$ day of observation in the same group of patients, 16 microorganisms were isolated, among them were S. aureus (30.5\%), E. coli $(25.1 \%)$ and PS. aerug. $(9.7 \%)$. The level of microbial colonization, expressed in decimal logarithms was lg $(9.1 \pm 0.3) \mathrm{CFU} / \mathrm{ml}$.

On the $5^{\text {th }}$ day, despite the species diversity among the selected microorganisms (28 isolates), a significant decrease (7 strains) in microbial colonization was recorded in dynamics to an amount of $\lg (4.8 \pm 0.4) \mathrm{CFU} / \mathrm{ml}$ respectively and did not exceeded the given critical level (lg $5 \mathrm{CFU} / \mathrm{ml}$ ).

The number of microorganisms which accounted for a significant percentage, were significantly decreased S. aureus (15.2\%), E. colli (9.6\%) (Table 1).

When Dekasan was used, positive dynamics were obtained in reduced strains and the number of colonies of microorganisms, which indicates a high efficiency of used drug (Fig. 1). Also there is an improvement in indicators of the clinical blood test from the moment of beginning till the end of the therapy. In particular, the normalization of the White blood cell differential and a decrease in the ESR.

In the $2^{\text {nd }}$ study group $(n=15)$, antiseptic treatment of patients was carried out with drug Cutasept G. At first the bacteriological culture was done before treatment started, in which 32 strains of microorganisms were found. The quantitative amount of microorganisms in the exudates, expressed in decimal logarithms reached $\lg (9.6 \pm 0.4) \mathrm{CFU} / \mathrm{ml}$. The most common isolates found of bacteria found were $S$. aureus (45.3\%), Ps. aerug. $(37.3 \%)$ and Pr. vulgaris (30.1\%).
Table 1. Results of bacteriological investigation (quantity measurement) by day (group No. 1, Decasan)

\begin{tabular}{|c|c|c|c|}
\hline № & $\begin{array}{c}\text { Before } \\
\text { treatment }\end{array}$ & $3^{\text {rd }}$ day & $5^{\text {th }}$ day \\
\hline 1 & $5 \times 10^{8}$ & $3 \times 10^{5}$ & Not revealed \\
\hline 2 & $6 \times 10^{7}$ & Not revealed & Not revealed \\
\hline 3 & $9 \times 10^{7}$ & $3 \times 10^{5}$ & $2 \times 10^{5}$ \\
\hline 4 & $9 \times 10^{8}$ & $5 \times 10^{8}$ & $3 \times 10^{6}$ \\
\hline 5 & $6 \times 10^{7}$ & $4 \times 10^{5}$ & $4 \times 10^{4}$ \\
\hline 6 & $10 \times 10^{6}$ & $4 \times 10^{4}$ & Not revealed \\
\hline 7 & $8 \times 10^{8}$ & $3 \times 10^{6}$ & Not revealed \\
\hline 8 & $7 \times 10^{8}$ & $5 \times 10^{5}$ & Not revealed \\
\hline 9 & $5 \times 10^{8}$ & Not revealed & Not revealed \\
\hline 10 & $7 \times 10^{7}$ & $3 \times 10^{5}$ & $2 \times 10^{5}$ \\
\hline 11 & $9 \times 10^{8}$ & $9 \times 10^{8}$ & $3 \times 10^{6}$ \\
\hline 12 & $6 \times 10^{7}$ & $4 \times 10^{5}$ & $4 \times 10^{4}$ \\
\hline 13 & $10 \times 10^{6}$ & $4 \times 10^{4}$ & Not revealed \\
\hline 14 & $5 \times 10^{8}$ & $3 \times 10^{6}$ & Not revealed \\
\hline 15 & $10 \times 10^{6}$ & $6 \times 10^{5}$ & $4 \times 10^{4}$ \\
\hline
\end{tabular}

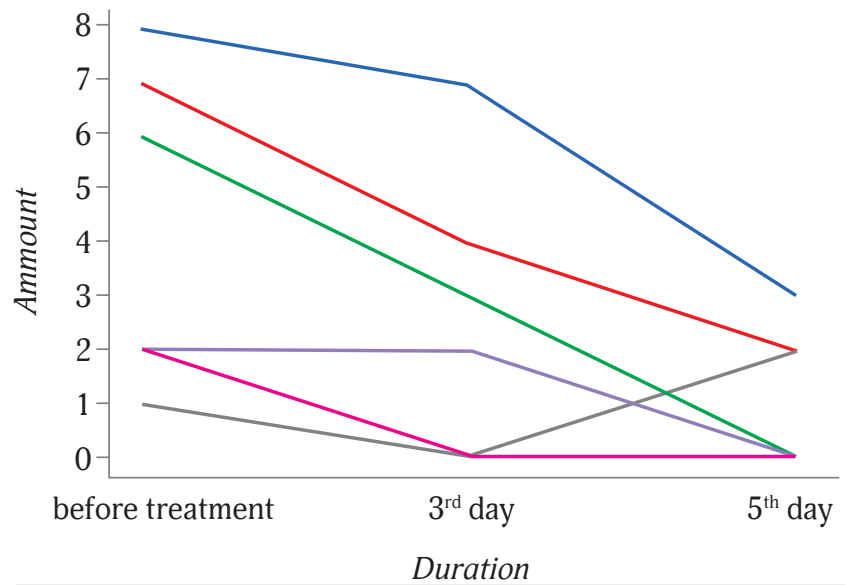

Bacteria:

$\begin{array}{ll}\text { S. aureus } & \text { Ps. aerug. }- \text { Ent. faecium } \\ \text { Pr. vulgaris } & \text { E. coli }\end{array}$

Fig. 1. The dynamics of reducing the number of strains of microorganisms by day (group No. 1, Dekasan)

On the $3^{\text {rd }}$ day of the observation, 27 microorganisms were isolated from patients of the given observation group, among them S. aureus (35.2\%), Pr. vulgaris (25.3\%) and Ps. aerug. (30.7\%). The level of microbi- 
Table 2. Results of bacteriological investigation (quantity measurement) by day (group No. 2, Cutasept G)

\begin{tabular}{lccc}
\hline № & Before treatment & $3^{\text {rd }}$ day & $5^{\text {th }}$ day \\
\hline 1 & $8 \times 10^{8}$ & $8 \times 10^{8}$ & $5 \times 10^{8}$ \\
\hline 2 & $7 \times 10^{7}$ & $7 \times 10^{6}$ & $4 \times 10^{5}$ \\
\hline 3 & $9 \times 10^{8}$ & $9 \times 10^{8}$ & $5 \times 10^{8}$ \\
\hline 4 & $9 \times 10^{7}$ & $9 \times 10^{7}$ & Not revealed \\
\hline 5 & $6 \times 10^{7}$ & $4 \times 10^{7}$ & $4 \times 40^{7}$ \\
\hline 6 & $9 \times 10^{7}$ & $7 \times 10^{7}$ & $5 \times 10^{7}$ \\
\hline 7 & $5 \times 10^{7}$ & $5 \times 10^{7}$ & Not revealed \\
\hline 8 & $8 \times 10^{7}$ & $5 \times 10^{7}$ & $5 \times 10^{7}$ \\
\hline 9 & $8 \times 10^{8}$ & $8 \times 10^{8}$ & $5 \times 10^{8}$ \\
\hline 10 & $6 \times 10^{7}$ & $6 \times 10^{7}$ & $4 \times 10^{5}$ \\
\hline 11 & $9 \times 10^{8}$ & $9 \times 10^{8}$ & $5 \times 10^{8}$ \\
\hline 12 & $9 \times 10^{7}$ & $9 \times 10^{7}$ & $7 \times 10^{7}$ \\
\hline 13 & $6 \times 10^{7}$ & $4 \times 10^{7}$ & $4 \times 10^{7}$ \\
\hline 14 & $5 \times 10^{7}$ & $4 \times 10^{7}$ & $4 \times 10^{7}$ \\
\hline 15 & $8 \times 10^{7}$ & $5 \times 10^{7}$ & Not revealed \\
\hline & & &
\end{tabular}
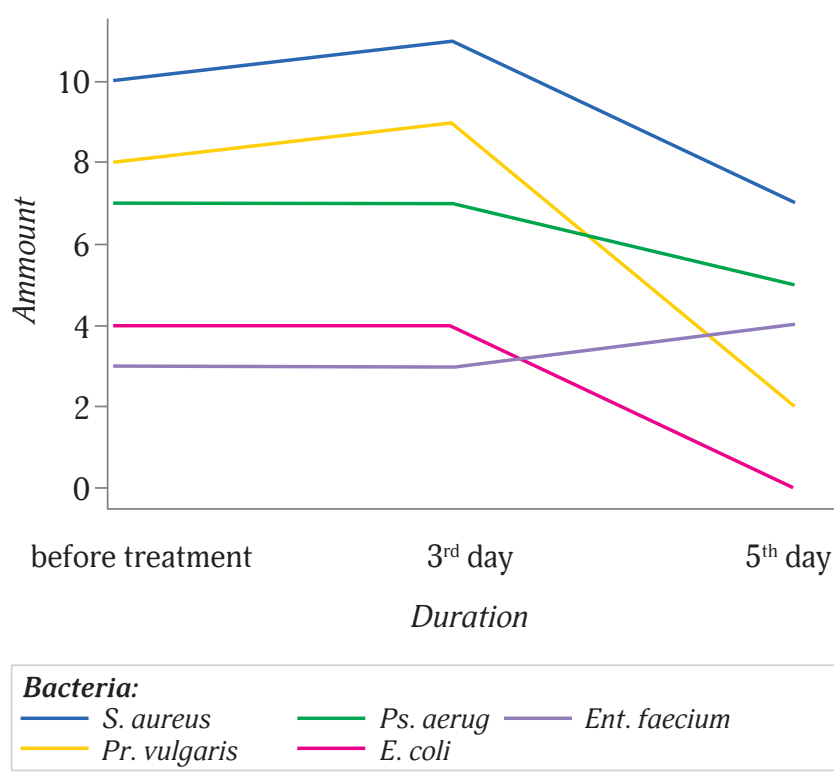

Fig. 2. The dynamics of reducing the number of strains of microorganisms by day (group No.2, Cutasept $G$ )

al colonization, expressed in decimal logarithms, was $\lg (9.1 \pm 0.3) \mathrm{CFU} / \mathrm{ml}$.

On the $5^{\text {th }}$ day, despite the species diversity among the selected microorganisms (32 isolates), a decrease (18 strains) of microbial colonization was recorded in dynamics to the amount of $\lg (8.8 \pm 0.4) \mathrm{CFU} / \mathrm{ml}$, which exceeds the acceptable critical level (lg $5 \mathrm{CFU} / \mathrm{ml}$ ). The numbers of microorganisms were decreased S. aureus $(20.2 \%)$, Ps. aerug. (9.6\%) (Table 2). The dynamics of reducing the number of microorganisms is displayed graphically (Fig. 2).

Analyzing the results of bacteriological studies of both groups, at first when Dekasan was used and secondly after the use of Cutasept $G$, it was found that at the beginning of treatment there was a pronounced microbial colonization of wounds that did not significantly vary in patients of both observation groups $(p<0.05)$. During the microbiological monitoring in the course of the purulent-inflammatory process in dynamics showed that there was a significantly slowed down process of microbial purification in the second group (Cutasept $\mathrm{G}$ ), the data gave results on the $5^{\text {th }}$ day were $\lg (8.8 \pm 0.4)$ $\mathrm{CFU} / \mathrm{ml}$. At that time, when in the patients of the first comparison group, the number of microorganisms in $1 \mathrm{ml}$ of wound content, expressed in lg, were $(4.8 \pm$ $0.4) \mathrm{CFU} / \mathrm{ml}$, which does not exceed the critically acceptable level. The obtained values were significantly higher than when using Cutasept $G(p<0.05)$, which was two times higher than the level of microbial colonization as compared with the treatment of wounds with $0.02 \%$ decamethoxine solution $(\mathrm{p}<0.001)$.

\section{Conclusions}

In the use of an antiseptic agent of $0.02 \%$ decamethoxine during the treatment period of patients with purulent inflammatory diseases on $5^{\text {th }}$ day provided a decline in the number of the pathogenic microorganisms lg $(4.8 \pm$ $0.4) \mathrm{CFU} / \mathrm{ml}$. which is 1.9 times $(\mathrm{p}<0.05)$ as compared with the use of Cutasept $\mathrm{G}$, which creating conditions for the colonization of normal skin microbiota (Corynebacterium spp. and S. epidermidis).

The antiseptic drug Dekasan can be characterized by a good healing ability due to its high antimicrobial activity, isotonicity, which makes it possible to be successfully used it in patients with purulent inflammatory diseases of various localization. In addition, the usege of Dekasan helps to quickly cleanse wounds from purulent-necrotic contents and the formation of granulation tissue in it.

The the practiced prolonge use of Dekasan shows that the drug is well tolerated by patients without a toxic effects on the body, without side effects and allergic manifestations. In the future, it is advisable to expand research on the properties of this drug in patients with various localization of purulent inflammatory diseases. 


\section{References}

1. Petrov SV. General Surgery. St. Petersburg: Publishing House "Lan", 2001:672

2. Diagnosis and treatment of anaerobic non-clostridial infection of soft tissue. Guidelines. - Minsk, 1999.

3. Gobrach OO, Nazarchuk OA, Paliy DV, Kovalenko IV, Yatsula OV. Study of antimicrobial properties of antiseptic drugs which contain decamethoxine ${ }^{\circledR}$. Ukrainian Bio pharmaceutical Journal. 2016; 1: 74-77

4. Paliy VG, Moroz VM, Zheliba MD, Humeniuk MI, Safronov KM. Antimicrobial drug Dekasan ${ }^{\circledR}$ : Strategy and Tactics for the prevention and treatment of purulent inflammatory diseases. Consilium medicum Ukraina, 12. Retrieved from: http://www.consilium-medicum.com.ua/issues/1/31/245

5. Norman G, Christie J, Liu Z, Westby MJ, Jefferies JM, Hudson T, Edwards J, Mohapatra DP, Hassan IA, Dumville JC. Antiseptics for burns. Cochrane Database of Systematic Reviews. 2017(7).
6. Verstraelen H, Verhelst R, Roelens K, Temmerman M. Antiseptics and disinfectants for the treatment of bacterial vaginosis: A systematic review. BMC Infectious Diseases [Internet]. Springer Science and Business Media LLC; 2012 Jun 28;12(1). Available from: https://doi.org/10.1186/1471-2334-12-148

7. Instruction No. 25/06/07 for the use of the Cutasept $\mathrm{G}$ disinfectant, skin antiseptic agent, "BODE Chemie GmbH and coop.", Germany, 2007

8. Krasilnikov AP. Handbook of Antisepsis, Minsk: Minsk school; 1995.

9. Faustova MO, Nazarchuk OA, Ananieva MM. Antistreptococcal activity of antibiotics and antiseptics. Actual problems of modern medicine, 2 (58); 2017. Retrieved from http:// elib.umsa.edu.ua/ jspui/handle/umsa/1409.

\section{Порівняльна характеристика ефективності антисептичних препаратів Декасан (DECASAN) Юрія-Фарм і Кутасепт Г (CUTASEPT G) при лікуванні гнійно-запальних захворювань різної локалізації}

Лихман В. Н., Ткач С. В.

ДУ “нститут загальної та невідкладної хірургії ім. В. Т. Зайцеева НАМН України”, Харків

Резюме. Актуалізація: Висока летальність як наслідок різних інфекційних ускладнень (у 42,5\% випадків є безпосередньою причиною), постійне збільшення частоти гнійно-запальних захворювань, а також зростання мікробної стійкості до антибактеріальних препаратів змушують шукати вирішення проблеми серед місцевих антисептиків.

Мета дослідження: Порівняти ефективність антисептиків - Декасан (DECASAN) Юрія-Фарм і Кутасепт Г (CUTASEPT G) при лікуванні гнійно-запальних захворювань різної локалізації.

Матеріали і методи: У дослідженні взяли участь 30 пацієєнтів з гнійно-запальними захворюваннями різної локалізації. Відповідно до обраної тактики місцевої антисептичної терапії хворі були розділені на дві групи. У хворих першої досліджуваної групи $(n=$ 15 , середній вік - 49,73 \pm 6,35 року) антисептична обробка проводилася лікарським засобом на основі 0,02\% декаметоксину (Декасан). У другій групі ( $n=15$, середній вік - 51,4 \pm 5,14 року) обробка проводилася дезінфікуючим засобом (шкірним антисептиком) “Кутасепт Г”. Забір матеріалу для мікробіологічного дослідження (бактеріологічний посів) проводили до початку лікування, на 3 і 5 добу після початку лікування. Аналіз імовірності проводився за t-критерієм Стьюдента. Статистично значущою різницю між показниками вважали при ймовірності справедливості нульової гіпотези менше $5 \%(p<0,05)$.

Результати. Аналізуючи отримані результати бактеріологічного дослідження обох груп, у першій, коли застосовувався Декасан, і в другій, після застосування Кутасепт Г, було встановлено, щзо на початку лікування мала місце виражена мікробна колонізація ран, що достовірно не відрізнялася у пацієнтів обох груп спостереження $(p<0,05)$. Мікробіологічне спостереження за перебігом гнійно-запального процесу в динаміці свідчило про значно уповільнений процес мікробного очищення в другій групі (Кутасепт Г), стан на 5 добу було $\lg (8,8 \pm 0,4)$ КУО/мл, в той час коли у пацієнтів першої групи порівняння - кількість мікроорганізмів в 1 мл ранового вмісту, виражене в $\mathrm{Ig}$, склало $(4,8 \pm 0,4)$ КУО/мл, щзо не перевищує критично допустимий рівень. Отримані показники були достовірно вищі, ніж при застосуванні Кутасепт $\Gamma(p<0,05)$, що вдвічі перевищували рівень мікробноі колонізації порівняно з обробкою ран 0,02\% розчином декаметоксину $(p<0,001)$.

Висновок. Застосування антисептика 0,02\% декаметоксину на 5 добу забезпечує зменшення кількості умовно-патогенних мікроорганізмів $\lg (4,8 \pm 0,4)$ КУО/мл, тобто в 1,9 раза нижче $(p<0,05)$ порівняно з застосуванням Кутасепт $Г$, що створює умови для заселення нормальної мікробіотою шкіри (Corynebacterium spp., S. epidermidis).

Антисептичний препарат Декасан характеризується хорошою лікувальною здатністю завдяки високій протимікробній активності, ізотониччностиі, щз дає можливість успішно застосовувати його у хворих з гнійно-запальними захворюваннями різноі локалізації. Крім цьього, застосування Декасану сприяє швидкому очищенню ран від гнійно-некротичного вмісту та утворенню в них грануляційної тканини.

Ключові слова: Декаметоксин, гнійно-запальні захворювання, S. aureus, Ps. aeruginosa, антибіотикорезистентність 